\title{
TERRITORIAL DIMENSION FOR SUSTAINABLE DEVELOPMENT OF INFRASTRUCTURE ENTERPRISES: INFORMATION AND ADMINISTRATIVE COMPONENT
}

\author{
Inna Zablodska ${ }^{1}$, Yuliia Rohozian ${ }^{2 *}$, Oleksandra Melnykova ${ }^{3}$ Oksana Romakhova ${ }^{4}$, Serhii \\ Karielin $^{5}$
}

${ }^{1}$ Department of Interregional Cooperation Issues, State Organization "V.K. Mamutov Institute of Economic and Legal Research of the National Academy of Sciences of Ukraine"

${ }^{2}$ Department of Interregional Cooperation Issues, State Organization "V.K. Mamutov Institute of Economic and Legal Research of the National Academy of Sciences of Ukraine” * Corresponding author.

E-mail address: j.s.rohozian@gmail.com

${ }^{3}$ Department of Business Economics and Entrepreneurship, Kyiv National Economic University named after Vadym Hetman

${ }^{4}$ Department of Public Management and Marketing, Volodymyr Dahl East Ukrainian National University

${ }^{5}$ Department of Interregional Cooperation Issues, State Organization "V.K. Mamutov Institute of Economic and Legal Research of the National Academy of Sciences of Ukraine"

Received 1608 2021; Accepted 30082021

\begin{abstract}
The article reveals important territorial aspects of sustainable development of infrastructure enterprises from information and administrative component on the example of local territories (communities) of the Donetsk region in Ukraine. A point-rating evaluation of the territorial dimension for sustainable development of infrastructure enterprises in the Donetsk communities carry out on the parameters, which focus on a set of statistical data in the context of the economic, social and environmental components. The authors built a three-dimensional model of the evaluation results in a Cartesian coordinate system, which made it possible to identify a direct relationship between the sustainable development components of infrastructure enterprises as well as its information and administrative support. It concluded to strengthen the sustainable development components in the local measurement as well as it substantiated and noted to form a special roadmap for ensuring high-quality information and administrative support for the sustainable development planning of infrastructure enterprises.
\end{abstract}

Key words: sustainable development, infrastructure enterprises, strategy, information and administrative support, local territories, point-rating evaluation, Donetsk region, Ukraine.

JEL Codes: H54; O30; O18.

\section{Introduction}

Modern economic conditions dictate to ensure the competitiveness of regional and local economic systems. There, one of the leading roles played by ensuring the sustainable development of infrastructure enterprises as well as it is the dominant component of the development concept in many European countries, including Ukraine.
The low level of information and administrative support for the sustainable development of infrastructure enterprises significantly reduces the chances of territories, especially small ones - at the local level - to achieve economic, social and environmental competitive positions among similar socio-economic systems.

Copyright (C) 2021 Author(s), published by Vytautas Magnus University. This is an open access article distributed under the terms of the Creative Commons Attribution Non-Commercial 4.0 (CC BY-NC 4.0) license, which permits unrestricted use, distribution, and reproduction in any medium provided the original author and source are credited. The material cannot be used for commercial purposes. 
Since it creates obstacles for ensuring the areas` attractiveness, and then attracting the necessary resources. To solve the above problem, it is extremely important to pay attention for providing the proper quality of information (actual statistical data, analytical materials, etc.) and making informed local administrative decisions on the development of infrastructure enterprises (economic, social and environmental), which play an important role in ensuring the well-being of each local administrative and territorial unit.

On the other hand, the priority direction of Ukraine's foreign policy is the integration process into the European Union, within the framework of which our country is obliged to harmonize its legislative base with the European one, including the principles of sustainable development. The provisions of the draft Sustainable Development Strategy "Ukraine - 2030" provide for the regional development of infrastructural support in almost every strategic goal. This is indirectly to those cardinal changes that have occurred in Ukraine in recent years, associated with the course towards European integration, which make it possible to plan regional and local development based on the principles of sustainable development. Initially, local governments focus on creating a positive, attractive image of their area precisely through the prism of the economic, social and environmental sustainable components of infrastructure enterprises, where information and administrative support play a critical role as a dominant factor in the implementation of sustainable development goals.

The issues of theoretical and methodological imperative in relation to the infrastructural support of sustainable development in local territories have been researched quite widely by foreign and domestic scientists, among which J. MilánGarcía, J. Uribe-Toril (Milán-García, UribeToril et al., 2019), F. Blomsma, G. Brennan (Blomsma, Brennan, 2017), J. Xiangfeng, U. Muhammad, A. Shahid (Xiangfeng, Muhammad, Shahid et al., 2020), V. Šipilova, I. Ostrovska, E. Jermolajeva (Šipilova,
Ostrovska, Jermolajeva et al., 2017), I. Budnikevich and O. Kolomytseva (Budnikevich, Kolomytseva et al., 2021), Z. Siryk, N. Popadynets, M. Pityulych (Siryk, Popadynets, Pityulych et al., 2021), M. Munasinghe (Munasinghe, 2020), I. Zablodska, S. Hrechana (Zablodska, Hrechana et al., 2020), etc. Scientists focus on the need to restore critical infrastructure facilities in conflict territories, forgetting to analyze the current state of sustainable development of infrastructure enterprises. Nevertheless, evaluation their results based on the information and administrative features arises as an integral strategic development component of local territories. We are trying to correct this omission by conducting this scientific research, the purpose of which is to investigate the state of sustainable development of infrastructure enterprises through the information and administrative prism as well as to determine the conceptual imperatives of this process.

The methodological basis of this article is several general and specific methods for the research, among which it is necessary to single out systemic, complex, comparative, index, factorial. It used allowed to analyse the enterprises` state of social, industrial, transport infrastructure and present the scientific results of a point-rating evaluation of the territorial dimension for sustainable development of infrastructure enterprises of the local communities in Donetsk region, that bases on scientific conclusions about the need to strengthen the information and administrative component of this process. For it, the authors analyzed the current strategic documents for the development of territorial communities for the availability of information and administrative support and presented the parameters for measuring the sustainable development of infrastructure enterprises in order to establish a connection between the above processes.

Thus, the parameters for measuring sustainable development of infrastructure enterprises has been proposed by authors (Rohozian, Zablodska, Liashenko, 2021), 
focusing on the statistical data of infrastructure enterprises (social, economic and environmental). For each of these parameters, a study was carried out based on the analysis of reliability and quality criteria of the obtained information base about infrastructure enterprises (official statistics, analytical materials, expert surveys), as well as the adoption of informed administrative decisions (representative surveys of local authorities and self-government, infrastructure enterprises of communities in the Donetsk region). Given the multivarity of the survey results and the available evidence, their further research requires quantification and calculation of the weighted average values of indicators in a certain parameter of measuring the sustainable development in each local territory (community). Thus, the data obtained collected in a total evaluation using the point-rating method.

Using the available statistical and analytical data on the development of local Donetsk territories, their scoring carried out because of the following conditions: maximum score - 10 points - is assigned to the area with the best indicator result relative to the group of competitors; points calculation received by the community for a certain indicator is carried out by comparing their actual values with the best in the given set:

$$
L_{i}=\frac{\mathrm{I} n_{\mathrm{i}}}{\mathrm{I} n_{\max }} \times L_{\max }
$$

where $L_{i}$ - points for the $i$-th indicator; $I n_{i}-$ value of the estimated indicator; $I n_{\max }-$ value of the indicator with the best result; $L_{\mathrm{Max}}$ - maximum number of points (in this case 10.00).

Based on the quantified indicators, the values of indicators reflecting the state of sustainable development for infrastructure enterprises in a certain parameter $\left(L X n_{i}^{j}\right)$, which are calculated using the weighted average method. The final value of the rating evaluation of the each studied community in the context of the economic, social and environmental group of parameters $A_{L n}$ determined by the formula:

$$
\begin{gathered}
A_{L n}=\sqrt{\left(1-L X n_{i}^{\mathrm{Aj} j}\right)^{2}+}(1- \\
\left.L X n_{i}^{\mathrm{B} j}\right)^{2}+\left(1-L X n_{i}^{\mathrm{C} j}\right)^{2} \\
\text { where } L X n_{i}^{\mathrm{A}, \mathrm{B}, \mathrm{C} j}-\text { weighted average }
\end{gathered}
$$
values of indicators in the economic, social and environmental group of parameters in the context of local territories.

\section{Results}

The objects of local infrastructure include facilities located in a certain area and providing material production enterprises, organizations, non-productive institutions and the population of this area with services for transportation and storage of products, information transfer, movement of people, supply of material resources, including water, heat, gas, and electricity (Šipilova, Ostrovska, Jermolajeva et al., 2017).

Production infrastructure serves enterprises and organizations in the field of material production, primarily in industry, agriculture and construction. Production infrastructure understood as a set of industries, i.e. organizationally separated objects that ensure the normal course of social production through the provision of services. In particular, the infrastructure includes enterprises and organizations of electricity, heat and gas supply, transport enterprises of various types, logistics and sales of products, enterprises for information and business services, etc.

Social infrastructure is a main part of the general infrastructure, a set of industries that specialize in serving the population. The purpose of creating social infrastructure is to meet the needs of people living within a certain area. According to the functions provided by individual branches of social infrastructure, the following functional blocks can be distinguished in it: educational (preschool institutions, school education, vocational technical education, science); health (health care, environmental protection, sports, and tourism); household (housing, 
utilities, and household services); trading; communicative.

Due to the fundamental difference in the nature of services provided to the population, it is advisable to allocate within the social infrastructure. It combines facilities that create certain material living conditions for people (housing and communal services, household services, trade and catering, passenger transport, communications) and socio-cultural infrastructure - provides spiritual needs (educational, cultural and arts, health care institutions, institutions of physical culture and sports, social security institutions). The composition of social infrastructure varies greatly in each country depending on economic, natural, national, cultural, environmental and other conditions of state/regional development (Nebava, Tkachuk, 2019).

Thus, due to the armed conflict in eastern Ukraine between Ukraine and the Russian Federation, which began in 2014, part of Luhansk and Donetsk regions came out of Ukraine's control. The hostilities led to the collapse and destruction of infrastructure enterprises, so to ensure their sustainable development in the current pandemic, it is advisable to analyze the state of social, transport, industrial, infrastructure enterprises and their information and administrative support for the next steps according the research methodology.

According to the provisions of The Development Strategy of Donetsk region for the period up to 2027, the key components of long-term regional development is the sustainable development of enterprises in various areas of infrastructure. However, the most economically feasible and justified are the provisions about the need for sustainable development for enterprises of social, transport and industrial infrastructure, taking into account their recovery after the consequences of hostilities and their critical need for the normal provision of life for the population.

The practice of managing micro- and meso-level facilities confirm the direct importance of the information and administrative development components for infrastructure enterprises that arise as basic ones in the structural and institutional architectonics of local territories. Thus, the analysis of local documents regulating the development of territories and their infrastructure enterprises proves the fragmentation introduction of the administrative component of this process. It is considered by representatives of local authorities only as a set of elements for the use of effective forms and methods of management, ignoring the formation and implementation of priority goals and directions for the infrastructure enterprises development in the context of their sustainable development.

In addition, there is no justification and application of any diagnostic methods to determine the current state and the formation of sustainable development directions for enterprises (Blomsma, Brennan, 2017) of infrastructure in the Donetsk region in a strategic perspective. It creates significant barriers to the formation of an attractive investment image and attractiveness local territories (communities) of a given region. As for the information component of sustainable development of infrastructure enterprises, in practice, it comes into its expression in the form of organizational and administrative, primary accounting, financial, reporting and statistical, planning, resource, regulatory and technical and other documentation (Siryk, Popadynets, Pityulych et al., 2021). However, this pool of official documents is capable of providing only a tactical influence on the local development of the Donetsk region, unfairly ignoring the effective functioning of infrastructure enterprises in case of any changes in the internal (endogenous) and external (exogenous) environment. Moreover, a particularly important role in this process should be played by strategic documents (in addition to the development strategy implementation plans, programs, concepts, road maps, guidelines) aimed at ensuring balanced and long-term sustainable development of local infrastructure facilities. 
In order to solve these problems, it is vital to focus on in-depth and systematic work on the formation and implementation of local regulations aimed at ensuring sustainable development of infrastructure enterprises in the local territories. To implement these steps, it is important to assess the attractiveness of local territories in the eastern region of Ukraine in the above context by involving key stakeholders at a certain level of management, as well as representatives of the scientific and expert environment.

Data on the development of infrastructure enterprises is the basis for analyzing the attractiveness of local territories in the Donetsk region through the sustainable development prism (social, economic and environmental) based on the parameters with data

(Table

Table 1. Results of the point-rating evaluation of the territorial dimension for sustainable development of infrastructure enterprises of the communities in the Donetsk region, evaluated by authors according to (Donetsk Regional State Administration, 2020; Decentralization power in Ukraine, 2021)

\begin{tabular}{|c|c|c|c|c|c|c|c|c|c|c|}
\hline \multirow{3}{*}{$\begin{array}{c}\text { Values of parameters for } \\
\text { measuring sustain-nable } \\
\text { development of } \\
\text { infrastructure enter-prises } \\
\text { (on June, 2021) }\end{array}$} & \multicolumn{10}{|c|}{ Local territories (territorial communities) of the Donetsk region, their symbols } \\
\hline & $\begin{array}{c}\text { Andriivka } \\
\text { TC }\end{array}$ & $\begin{array}{l}\text { Zvanivka } \\
\text { TC }\end{array}$ & $\begin{array}{c}\text { Illinivka } \\
\text { TC }\end{array}$ & $\begin{array}{c}\text { Lyman } \\
\text { TC }\end{array}$ & $\begin{array}{r}\text { Mykolai } \\
\text {-ivka TC }\end{array}$ & $\begin{array}{l}\text { Oleksand- } \\
\text { rivka TC }\end{array}$ & $\begin{array}{c}\text { Siversk } \\
\text { TC }\end{array}$ & $\begin{array}{c}\text { Soledar } \\
\text { TC }\end{array}$ & $\begin{array}{c}\text { Cherkaske } \\
\text { TC }\end{array}$ & $\begin{array}{c}\text { Shahove } \\
\text { TC }\end{array}$ \\
\hline & A & $\mathbf{Z}$ & I & $\mathbf{L}$ & $\mathbf{M}$ & $\mathbf{O}$ & $\mathbf{C}$ & $\mathbf{D}$ & $\mathbf{H}$ & $\mathbf{W}$ \\
\hline \multicolumn{11}{|c|}{ Economic parameters } \\
\hline \multicolumn{11}{|c|}{ Parameter A1 } \\
\hline $\begin{array}{l}\text { - incomes of the general fund } \\
\text { per } 1 \text { inhabitant, UAH }\end{array}$ & 17639,90 & 2963,40 & 7057,60 & 6256,70 & 5083,30 & 4123,90 & 1368,20 & 6981,60 & 2897,70 & 18079,90 \\
\hline \begin{tabular}{|c|c|}
$L_{i}$ & \\
\end{tabular} & 9,76 & 1,64 & 3,90 & 3,46 & 2,81 & 2,28 & 0,76 & 3,86 & 1,60 & 10,00 \\
\hline $\begin{array}{l}\text { expenses of the general } \\
\text { fund per } 1 \text { inhabitant, UAH }\end{array}$ & 15423,50 & 2654,60 & 7984,20 & 11157,10 & 5119,20 & 6542,10 & 3426,00 & 8998,10 & 6119,00 & 14026,90 \\
\hline \begin{tabular}{|c|}
$\boldsymbol{L}_{i}$ \\
\end{tabular} & 10,00 & 1,72 & 5,18 & 7,23 & 3,32 & 4,24 & 2,22 & 5,83 & 3,97 & 9,09 \\
\hline $\begin{array}{l}\text { - level of subsidized budgets } \\
\text { (share of base / reverse } \\
\text { subsidies in income), \% }\end{array}$ & $-0,40$ & 12,90 & $-5,30$ & $-0,80$ & $-2,60$ & 11,40 & 45,50 & $-7,80$ & 40,60 & $-1,20$ \\
\hline$L_{i}$ & 0,51 & 0,06 & 6,79 & 1,02 & 3,33 & 0,07 & 0,01 & 10,00 & 0,02 & 1,54 \\
\hline \multicolumn{11}{|c|}{ Parameter A2 } \\
\hline $\begin{array}{l}\text { number of } \\
\text { (large and } \\
\text { (larprises } \\
\text { businesses) } \\
\text { people, units }\end{array}$ & 1,79 & 0 & 1,39 & 0,67 & 0,23 & 1,34 & 0,19 & 0,28 & 0,20 & 0,13 \\
\hline $\boldsymbol{L}_{i}$ & 10,00 & 0 & 7,76 & 3,74 & 1,28 & 7,49 & 1,06 & 1,56 & 1,12 & 0,73 \\
\hline $\begin{array}{l}\quad \text { number of } \begin{array}{r}\text { private } \\
\text { (small }\end{array} \\
\text { entrepreneurs } \\
\text { business) per } 1000 \text { people, } \\
\text { units }\end{array}$ & 8,95 & 13,93 & 20,86 & 29,54 & 2,32 & 1,88 & 8,64 & 10,24 & 8,28 & 5,38 \\
\hline $\boldsymbol{L}_{i}$ & 3,03 & 4,71 & 7,06 & 10,00 & 0,78 & 0,64 & 2,92 & 3,47 & 2,80 & 1,82 \\
\hline \begin{tabular}{|ll} 
average monthly salary, \\
UAH
\end{tabular} & 9377,00 & 6700,00 & 10262,00 & 9625,00 & 8998,32 & 8031,00 & 6397,30 & 10693,00 & 6680,00 & 8237,10 \\
\hline $\boldsymbol{L}_{i}$ & 8,77 & 6,26 & 9,60 & 9,00 & 8,41 & 7,51 & 5,98 & 10,00 & 6,25 & 7,70 \\
\hline \multicolumn{11}{|c|}{ Parameter A3 } \\
\hline $\begin{array}{l}\text { share of hard-surface } \\
\text { roads in the total length of } \\
\text { roads of community, } \%\end{array}$ & 48,51 & 68,39 & 93,00 & 95,49 & 51,30 & 74,66 & 78,37 & 75,77 & 65,00 & 94,12 \\
\hline & 5,08 & 7,16 & 9,74 & 10,00 & 5,37 & 7,82 & 8,21 & 7,93 & 6,81 & 9,86 \\
\hline $\begin{array}{l}\text { share of households } \\
\text { provided with centralized } \\
\text { water supply in the total } \\
\text { number of households in } \\
\text { community, } \%\end{array}$ & 30,00 & 75,80 & 62,00 & 78,00 & 19,00 & 12,46 & 70,00 & 77,37 & 18,00 & 18,00 \\
\hline$L_{i}$ & 3,85 & 9,72 & 7,95 & 10,00 & 2,43 & 1,60 & 8,97 & 9,92 & 2,31 & 2,31 \\
\hline $\begin{array}{l}\text { share of households } \\
\text { provided with centralized }\end{array}$ & 30,00 & 90,00 & 64,00 & - & 10,00 & 9,43 & 80,00 & 77,37 & 34,00 & 34,00 \\
\hline
\end{tabular}


Inna Zablodska, Yuliia Rohozian*, Oleksandra Melnykova, Oksana Romakhova, Serhii Karielin Territorial Dimension for Sustainable Development of Infrastructure Enterprises: Information and Administrative Component

\begin{tabular}{|c|c|c|c|c|c|c|c|c|c|c|}
\hline $\begin{array}{l}\text { gas supply, in their total } \\
\text { number, } \%\end{array}$ & & & & & & & & & & \\
\hline$L_{i}$ & 3,33 & 10,00 & 7,11 & - & 1,11 & 1,05 & 8,89 & 8,60 & 3,78 & 3,78 \\
\hline$L X n_{i}^{A j}$ & 6,04 & 4,58 & 7,23 & 6,81 & 3,20 & 3,63 & 4,33 & 6,80 & 3,18 & 5,20 \\
\hline \multicolumn{11}{|c|}{ Social parameters } \\
\hline \multicolumn{11}{|c|}{ Parameter B1 } \\
\hline $\begin{array}{l}\text { number of social } \\
\text { infrastructure institutions } \\
\text { supported by the budget of } \\
\text { local governments per } \\
1000 \text { people, units }\end{array}$ & 20,05 & 2,42 & 1,47 & 2,18 & 0,93 & 4,18 & 3,31 & 2,70 & 2,55 & 2,40 \\
\hline$L_{i}$ & 10,00 & 1,21 & 0,73 & 1,09 & 0,46 & 2,08 & 1,65 & 1,35 & 1,27 & 1,20 \\
\hline \begin{tabular}{|lrr} 
number of & general \\
practitioners, & family \\
doctors per & 1000 \\
population, units & \\
\end{tabular} & 0,57 & 0,30 & 0,50 & 0,30 & 0,12 & 0,42 & 0,30 & 0,30 & 0,42 & 2,41 \\
\hline $\boldsymbol{L}_{i}$ & 2,36 & 1,24 & 2,07 & 1,24 & 0,50 & 1,74 & 1,24 & 1,24 & 1,74 & 10,00 \\
\hline \multicolumn{11}{|c|}{ Parameter B2 } \\
\hline $\begin{array}{l}\text { number of births per } \\
1000 \text { people, people }\end{array}$ & 3,58 & 7,87 & 2,29 & 3,88 & 3,45 & 3,11 & 3,12 & 2,98 & 1,48 & 2,23 \\
\hline $\boldsymbol{L}_{i}$ & 4,55 & 10,00 & 2,91 & 4,93 & 4,38 & 3,95 & 3,96 & 3,79 & 1,88 & 2,83 \\
\hline $\begin{array}{l}\text { number of deaths per } \\
1000 \text { people, people }\end{array}$ & 19,69 & 10,60 & 7,77 & 12,14 & 10,32 & 10,79 & 9,24 & 10,19 & 7,94 & 4,81 \\
\hline $\begin{array}{c}L_{i} \\
\end{array}$ & 2,44 & 4,54 & 6,19 & 3,96 & 4,66 & 4,46 & 5,20 & 4,41 & 6,06 & 10,00 \\
\hline$L X n_{i}^{B j}$ & 4,84 & 4,25 & 2,97 & 2,80 & 2,50 & 3,06 & 3,01 & 2,70 & 2,74 & 6,01 \\
\hline \multicolumn{11}{|c|}{ Environmental parameters } \\
\hline \multicolumn{11}{|c|}{ Parameter C1 } \\
\hline $\begin{array}{l}\text { share of pollutants } \\
\text { emissions into the air in } \\
\text { the general educational } \\
\text { regional volume, } \%\end{array}$ & 0,44 & 0,05 & 0,51 & 0,02 & 3,03 & 0,04 & 0,03 & 1,67 & 0,05 & 0,07 \\
\hline \begin{tabular}{|c|}
$L_{i}$ \\
\end{tabular} & 0,45 & 4,00 & 0,39 & 10,00 & 0,07 & 5,00 & 6,67 & 0,12 & 4,00 & 2,86 \\
\hline $\begin{array}{l}\text { - number of the natural } \\
\text { reserve fund objects, units }\end{array}$ & 5 & 4 & 5 & 11 & 4 & 5 & 10 & 8 & 8 & 12 \\
\hline \begin{tabular}{|l|}
$\boldsymbol{L}_{i}$ \\
\end{tabular} & 4,17 & 3,33 & 4,17 & 9,17 & 3,33 & 4,17 & 8,33 & 6,67 & 6,67 & 10,00 \\
\hline \multicolumn{11}{|c|}{ Parameter C2 } \\
\hline $\begin{array}{l}\text { number of the history, } \\
\text { architecture, archaeology } \\
\text { monuments, units }\end{array}$ & 11 & 17 & 14 & 45 & 29 & 37 & 21 & 22 & 155 & 43 \\
\hline \begin{tabular}{c|}
$L_{i}$ \\
\end{tabular} & 0,71 & 1,10 & 0,90 & 2,90 & 1,87 & 2,39 & 1,35 & 1,42 & 10,00 & 2,77 \\
\hline $\begin{array}{l}\text { number of ongoing } \\
\text { projects in } 2020 \text { aimed at } \\
\text { increasing the tourist and } \\
\text { recreational potential of } \\
\text { community, units }\end{array}$ & 5 & 1 & 2 & 5 & 1 & 3 & 4 & 5 & 3 & 5 \\
\hline$L_{i}$ & 10,00 & 2,00 & 4,00 & 10,00 & 2,00 & 6,00 & 8,00 & 10,00 & 6,00 & 10,00 \\
\hline$L X n_{i}^{C j}$ & 3,83 & 2,61 & 2,36 & 8,02 & 1,82 & 4,39 & 6,09 & 4,55 & 6,67 & 6,41 \\
\hline
\end{tabular}

The Table 1 data help to build the Cartesian coordinate system (Figure 1) in space that is a triad of pairwise perpendicular axes (the abscissa axis shows the social component of the attractiveness parameters of local territories, the ordinate axis is the environmental component, the applicatu axis is the economic component), which have a common origin and the same scale along the axes. Each point in space, according to a certain rule, is assigned a triad of digits of the final value of the rating assessment of the study area in the context of the economic, social and environmental group of parameters of attractiveness $A_{L n}$ from Table 1.

In general, the conducted evaluation demonstrates the absence of a positive state for the sustainable development components of infrastructure enterprises in the Donetsk region, since the development of 9 out of 10 communities characterized by imbalance, which approaches the dominant manifestations of the environmental component.

Only the Soledar territorial community has clear features of the balance of its economic, social and environmental positions. 


\section{Sciendo}

Management Theory and Studies for Rural Business and Infrastructure Development eISSN 2345-0355. 2021. Vol. 43. No. 3: 354-362

Article DOI: https://doi.org/10.15544/mts.2021.32

Having analyzed the analytical documents of the presented local territories, one can draw a clear parallel between the information and administrative support for the development of infrastructure enterprises and the general level of their sustainable development - they are interconnected and directly correlate with each other. Therefore, the Soledar community is the only territory in eastern Ukraine that plans not only socio-economic indicators of its development, but also information and administrative ones, constantly questioning local residents about their thoughts on improving information and administrative support for strategic planning of the area.

Other communities of the Donetsk region in Figure 1 do not devote enough time and effort to this process, traditionally despite new trends in local development, which is a big mistake and slows down the economic, social and environmental development of these territorial units.

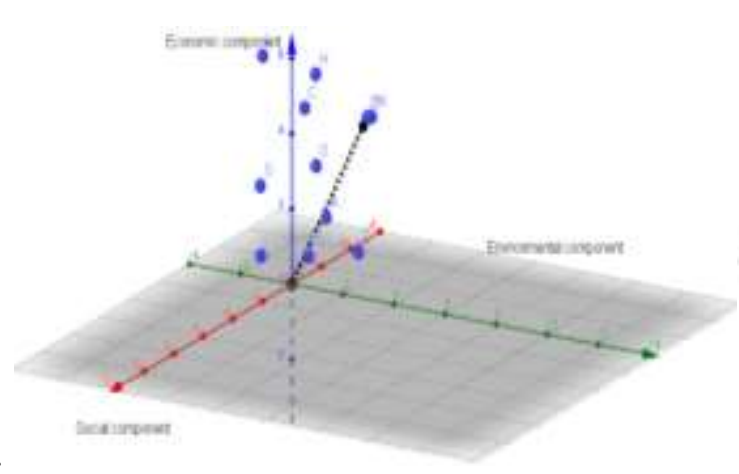

a)

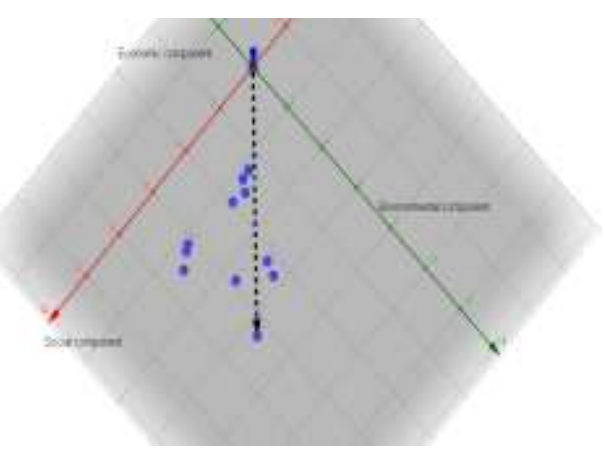

b)

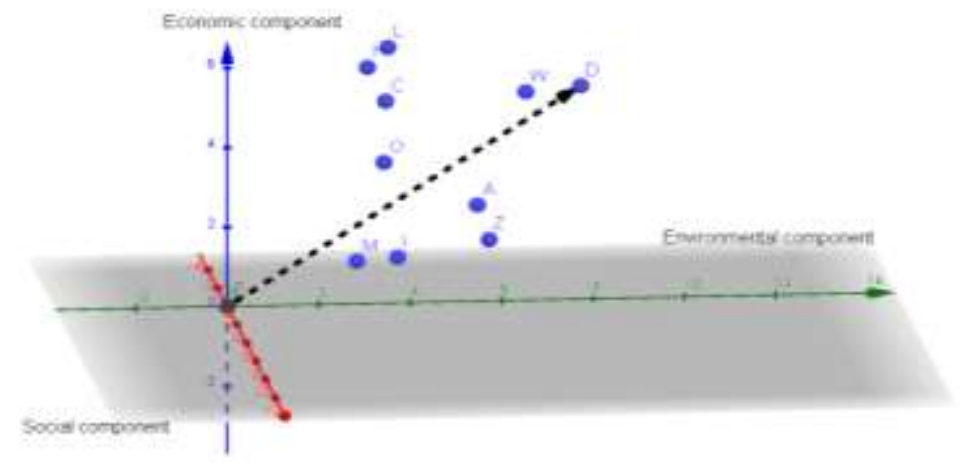

c)

Figure 1. A three-dimensional model of the results of a point-rating evaluation for territorial dimension of infrastructure enterprises in space (from the perspective a, b, c), built by authors

Copyright (C) 2021 Author(s), published by Vytautas Magnus University. This is an open access article distributed under the terms of the Creative Commons Attribution Non-Commercial 4.0 (CC BY-NC 4.0) license, which permits unrestricted use, distribution, and reproduction in any medium provided the original author and source are credited. The material cannot be used for commercial purposes. 
The results of assessing the sustainable development of infrastructure enterprises in the territorial dimension determine the importance of including the main provisions of information and administrative support of this process in the planning of the life activity of each local territory. The development of specific activities in the information and administrative direction in the context of the implementation of strategic goals for the development of infrastructure enterprises with respect to the formation of their image and reputation attractiveness, which ultimately leads to the accumulation of a positive reputation capital throughout the territory. The need to improve the existing state of information and administrative support for the sustainable development of infrastructure enterprises made it possible to focus on the development of a special roadmap or other algorithm of actions to improve the economic, social and environmental positions of the enterprises themselves and the territories within which they are located. Such an algorithm of actions should provide for three main stages: identification of factors of influence on the sustainable development of infrastructure enterprises and the image of their territories, the concept formation of such development and programming, the attitude of the target audience of territory to it. This should be a systematic, clear action plan designed to improve the information and administrative positions of the sustainable development of infrastructure enterprises. It should be primarily in the Luhansk and Donetsk regions, since the powerful work on their development will contribute to the design of positive associations in relation to them, the warming of relations between representatives of local territories from different corners as well as a powerful driver to restore their competitiveness against the backdrop of ongoing hostilities.

\section{Conclusions}

Issues related to ensuring sustainable development of infrastructure enterprises are increasing in the world every year, expanding scientific research in this area from a territorial point of view (Taecharungroj, Muthuta, Boonchaiyapruek, 2019). Infrastructure enterprises act as the foundation for the normal life of each territory, but they are especially important in the East of Ukraine, where the infrastructure potential has been damaged by military operations, therefore, the research was carried out on the example of the territorial communities of the Donetsk region.

Analysis of the latest statistical and analytical data on the development of infrastructure enterprises in the Donetsk region indicates its low level against the background of the loss of a significant number of critical infrastructure facilities during military operations. Despite this situation, representatives of local self-governments understand the importance of solving the problems of sustainable development of infrastructure enterprises, therefore, fragmentarily, but planning their development through this prism, can be seen in the corresponding development strategies until 2027.

At the same time, the information and administrative support for the strategic planning of local territories remains unsatisfactory, since the local authorities prioritize the achievement of relevant socioeconomic indicators. The available statistical data on the development of infrastructure enterprises formed the basis for the point-rating evaluation of its territorial dimension through the prism of the sustainable development (social, economic and environmental elements). The evaluation results on the example of the territorial communities of the Donetsk region confirm the deep imbalance in the components of sustainable development, especially in terms of economic and social communities' positions, where indicators of infrastructure enterprises play a major role.

A detailed analysis of the development strategies of the studied local territories proves a direct relationship between the level of sustainable development of their infrastructure enterprises and the almost complete absence of information and administrative support for this process. The need to take into account the peculiarities of the implementation of 
sustainable development concept on the territory of the Ukrainian administrativeterritorial units, including its information and administrative components, makes it possible to emphasize the need to develop a methodological approach for determining clear steps and measures of this complicated process. It is assumed that such an algorithm of actions or a roadmap should consist of several stages and provide for the territorial dimension of the current economic, social and environmental positions of infrastructure enterprises in order to identify their significant competitive advantages in comparison with other territories. This is a complex, multifaceted process, therefore, each stage of its implementation will require the consolidation of all target groups of consumers, where it is important to find a balance both between the components of sustainable development and between the categories of stakeholders to which the action of this or that parameter is directed, that requires further scientific research.

\section{References}

Milán-García, J., Uribe-Toril, J., Ruiz-Real, J.L., \& De Pablo Valenciano, J., 2019. Sustainable local development: an overview of the state of knowledge, in: Resources, 2019, 8(1), 1-18. https://doi.org/10.3390/resources8010031

Blomsma F., Brennan G., 2017, The Emergence of Circular Economy A New Framing Around Prolonging Resource Productivity, in: Journal of Industrial Ecology, 21(3), 603-614.

Xiangfeng, J., Muhammad, U., Shahid, A., Wajid, A., Kai, T., \& Zeeshan, K., 2020. Does fiscal decentralization and eco-innovation promote sustainable environment? A case study of selected fiscally decentralized countries, in: Sustainable Development, 29(1), 79-88. https://doi.org/10.1002/sd.2132

Šipilova, V., Ostrovska, I., Jermolajeva, E., Aleksejeva, L., \& Oḷehnovičs, D., 2017. Evaluation of Sustainable Development in Rural Territories in Latgale Region (Latvia) by Using the Conception of Smart Specialization, in: Journal of Teacher Education for Sustainability, 19(1), 82-105. https://doi.org/10.1515/jtes-2017-0006

Budnikevich, I., Kolomytseva, O., Krupenna, I., \& Zablodska, D., 2021. Positioning of the Amalgamated Territorial Communities of Ukraine through the Sustainable Development in the Conditions of Military Actions, in: Problemy Ekorozwoju, 16(1), 103-112. https://doi.org/10.35784/pe.2021.1.11

Siryk, Z., Popadynets, N., Pityulych, M., Chakii, O., Irtyshcheva, I., Panukhnyk, O. ... Lysyak, N., 2021. Decentralization of local self-government under the conditions of administrative-territorial reform in Ukraine, in: Accounting, 7, 1-10. https://doi.org/10.5267/j.ac.2021.2.006

Munasinghe, M., 2020. Covid-19 and sustainable development, in: International Journal of Sustainable Development, 23(1/2), 1-24. https://doi.org/10.1504/IJSD.2020.112182

Zablodska, I., Hrechana, S., \& Zablodska, D., 2020. The identification of the Luhansk region and the region act's according to the qualification of their sustainable development in the conditions of the joint forces, in: Problemy Ekorozwoju, 15(1), 197-210. https://doi.org/10.35784/pe.2020.1.21

Rohozian, Yu., Zablodska, D., Liashenko, P., 2021. Theoretical and methodical dominants evaluation for positioning results of territorial communities in the East of Ukraine, in: Economics. Ecology. Socium, 5(1), 56-65. https://doi.org/10.31520/2616-7107/2020.5.1-6

Nebava, M.I., Tkachuk, L.M., 2019. The regional development management. Vinnytsia, VNTU, https://web.posibnyky.vntu.edu.ua/fmib/25nebava_upravlinnya_regionalnym_rozvytkom/7_3.html (12.08.2021).

Donetsk Regional State Administration, 2020. The Development Strategy of the Donetsk region until 2027, https://dn.gov.ua/ua/strategiya-rozvitku-doneckoyi-oblasti-na-period-do-2027-roku(13.08.2021).

Donetsk Regional State Administration, 2020. COVID-19 in Donetsk region: 21 more deaths and more than 260 new cases of disease,https://dn.gov.ua/ua/news/covid-19-na-donechchini-zafiksovano-shche-21-smert-ta-ponad-260novih-vipadkiv-hvorobi (29.06.2021).

Parashar A., 2015, Reverberations of Environmental Crisis and its Relevance in Managing Sustainablity: an Ecocritical Reading of T.S. Eliot's The Waste Land, in: Cross Mark, 42(2), 159-172.

Taecharungroj V., Muthuta M., Boonchaiyapruek P., 2019. Sustainability as a place brand position: a residentcentric analysis of the ten towns near Bangkok, in: Place Branding and Public Diplomacy, 15(4), 210-228.

Decentralization Power in Ukraine, 2021. Analysis of financial indicators of ATCs in terms of 24 regions: rating for 2021, https://decentralization.gov.ua/news/13358 (14.08.2021). 